Research Article

\title{
Appraisal of menstrual hygiene management among women in a rural setting: a prospective study
}

\section{Geethu C.*, Elizabeth Phoeba Paul, Jasmin Elizabeth Thomas, Chintu S. Pullan, Hemalatha S., Sivakumar T.}

Department of Pharmacy Practice, Nandha College of Pharmacy, Erode, Tamil Nadu, India

\author{
Received: 10 June 2016 \\ Revised: 13 June 2016 \\ Accepted: 06 August 2016 \\ *Correspondence: \\ Dr. Geethu C., \\ E-mail: geethukrishnac@gmail.com
}

Copyright: (C) the author(s), publisher and licensee Medip Academy. This is an open-access article distributed under the terms of the Creative Commons Attribution Non-Commercial License, which permits unrestricted non-commercial use, distribution, and reproduction in any medium, provided the original work is properly cited.

\begin{abstract}
Background: Menstrual hygiene management has been defined as, women and adolescent girls using a clean menstrual management material to absorb or collect blood that can be changed in privacy as often as necessary for the duration of the menstruation period using soap and water for washing the body as required and having access to facilities to dispose of used menstrual management materials (UNICEF and WHO, 2014). Management of menstruation in a hygienic manner is essential for females because poor maintenance of hygiene during menstruation causes reproductive tract infections. The aim is to assess the practices of menstrual hygiene among women of age group 18-45 in a rural setting.

Methods: A prospective, randomised, observational study was carried out in the outpatient department of obstetrics and gynaecology in a rural setting using a well-designed questionnaire.

Results: Out of 186 study subjects, sanitary pads were used by $83.87 \%$.An adequate washing of external genitalia was followed, that is 3-4 times/day (51.61\%). Only $8.07 \%$ of them used vaginal washes.82.25\%seemed to change the sanitary pad before sleep. $38.37 \%$ used more than 4 pads per day. The frequency of baths varied from twice $(69.35 \%)$ to once $(25.8 \%)$ per day. Only $8.06 \%$ used OTC to manage menstrual pain.61.39\% of them stored the sanitary pads in the bathroom.67.74\% burnt, $16.12 \%$ threw along with domestic waste, $6.45 \%$ threw in open places and $9.67 \%$ buried the pads.

Conclusions: Overall, the study reported a satisfactory menstrual hygiene practice.
\end{abstract}

Keywords: Menstruation, Hygiene, Practices

\section{INTRODUCTION}

Menstruation the natural component of the reproductive cycle is the periodic vaginal bleeding with the shedding of the uterine mucosa that occurs one or two years following appearance of secondary sexual characteristics. The menstrual cycle which lasts between 26 and 30 days prepares the uterus to receive, nourish and protect a fertilised ovum. If the ovum is not fertilised a new cycle begins with a short period of bleeding called menstruation. The whole process occurs under the influence of hypothalamic and anterior pituitary hormones. ${ }^{1-4}$ Every mature female menstruates on an average of 3-5 days each month until menopause. Woman's period may not be the same every month and for every woman. Periods can be light, moderate or heavy and the length of the period also varies. ${ }^{2}$

Learning about hygiene during menstruation is a vital aspect of health education. Menstrual hygiene deals with the special health care needs and requirements of women during monthly menstruation. These areas of special concern include choice of the best "period protection" or 
feminine hygiene products, how often and when to change the feminine hygiene products, bathing care of the vulva and vagina as well as the supposed benefits of vaginal douching at the end of each menstrual period. ${ }^{2}$

Understanding how to manage hygiene during menstruation is essential for girls because poor maintenance of hygiene during menstruation results in several diseases such as reproductive tract infections, pelvic inflammatory diseases, urinary tract infections etc. which may result in infertility of the girls. ${ }^{5}$ Reproductive tract infections, has become a silent epidemic that devastates women's lives which closely relatesto poor menstrual hygiene. Every year approximately $10 \%$ of women worldwide are exposed to genital infections including urinary tract infections and bacterial vaginitis and $75 \%$ of women have a history of a genital infection. The common risk factors for vaginal infections include pregnancy and poor hygiene (both perineal and menstrual hygiene). ${ }^{5}$

Sanitary pads, tampons and menstrual cups are the available commercial products for women's hygiene during menstruation. ${ }^{2}$ Women and girls of the reproductive age need access to clean and soft, absorbent sanitary products for a long run and protect their health. ${ }^{6}$

The two common reasons why women choose sanitary pads are comfort and safety. The amount of money that women spend on these materials seems to depend on two factors: household budget and market prices. Cost was the third most common criterion. ${ }^{3}$ The other criteria were as follows: availability (6.5\%), ease of disposal (6.2\%), ease of reuse $(3 \%)$ and a lack of embarrassment when purchasing $(2.3 \%) .^{3}$

Provisions for good menstrual hygiene also include home-made remedies like pieces of cotton cloth which are either placed on a woman's undergarment or on a home- made belt that wraps around the waist. ${ }^{2}$ Majority of the respondents washed their sanitary pads before disposal, so that their blood could not be used to cast an evil spell leading to infertility or difficulties during childbirth according to their beliefs. ${ }^{3}$ It also revealed that mothers, television, friends, teachers and relatives were the main sources which provided information on menstruation to the adolescent girls. ${ }^{5}$

Good hygienic practices such as adequate washing of the genital area are essential during menstruation. ${ }^{6}$ The use of harmful materials such as ash, sand or sawdust to absorb their menstrual blood are rare. ${ }^{3}$ Sanitary material replacement frequency, depends on blood flow levels. ${ }^{3}$ These cloths can be washed, dried in sunlight and reused. $^{2}$

As the disposable sanitary pads are susceptible to growth of microorganisms by absorbing the moisture from the atmosphere and reducing their effectiveness, pads should be stored in a dry environment. Appropriate method of disposal of adsorbents must be adopted as disposable pads are not recyclable and they cause negative consequences on environment.

\section{METHODS}

This prospective, randomised, observational study was carried out in the out-patient department of Obstetrics and Gynaecology unit of a Government hospital in Tamil Nadu, South India over a period of 2 months from April, 2016 to June, 2016. A total of 186adults were personally interviewed from the age (18-45 years) meeting our inclusion criteria about their status of hygienic behaviour using a pre-designed and well-structured questionnaire as given in (Table 1). ${ }^{10}$ The purpose of the study and its importance were explained to the study subjects and the demographic details, socio-economic status, education, and occupation of each women were recorded in the welldesigned Pro forma. Data collected on the knowledge of menstruation and their practices of hygiene were entered in the Microsoft Excel sheet and were analyzed.

\section{RESULTS}

The study subjects of 186 were categorized into APL (above poverty line) and BPL (below poverty line) based on economic status as shown in the pie chart (Figure 1). $11.29 \%$ of the study subjects were illiterate, $64.51 \%$ received basic education while $24.19 \%$ were highly educated (Figure 2). The occupational status is illustrated in (Figure 3). The use of disposable sanitary pads were common in comparison with other alternatives like cloths (old/new fabrics), toilet papers and natural materials. $83.87 \%$ of subjects used sanitary pads whereas $16.12 \%$ used cloths (Figure 4). None of them used toilet papers or natural materials. Another important part of maintaining hygiene is adequate washing of external genitalia at every visit to toilet using vaginal wash during menstrual days in particular followed by hand washing using soap. When the frequency of washing external genitalia after the use of toilet was interviewed a good result was obtained as shown in (Figure 5). It is a pathetic situation to know that $1.61 \%$ of them had an inadequate washing.

As bathing is a part of maintenance of personal hygiene, one should follow it daily. Here, in our study we could see people who took baths once, twice and even thrice (Figure 6). 91.13\% didn't use OTC medications as per (Figure 7). In detail the survey of the cleaning agents used, revealed that half of them used only water to clean while some used water and soap, minority used vaginal wash (Table 2). Majority of them changed absorbents before going to sleep whereas few changed during midnight as in (Table 3). It is to be noted that changing pads during midnight was not to maintain hygiene but due to over bleeding. The use of the number of pads depend on the menstrual flow of individual usually and not as a part of hygiene. The evidence for this fact can be elicited from our study results shown in (Table 4). 
Table 1: Evaluation of menstrual hygiene practices.

\begin{tabular}{|c|c|}
\hline $\begin{array}{l}\text { 1.Kind of material used } \\
\text { during menstruation }\end{array}$ & $\begin{array}{l}\text { a) Sanitary pads b) Cloths } \\
\text { (old/new) c) Toilet papers } \\
\text { d) Natural materials }\end{array}$ \\
\hline $\begin{array}{l}\text { 2.Adequate washing of } \\
\text { external genitalia at } \\
\text { every visit to toilet }\end{array}$ & $\begin{array}{l}\text { a)1-2 times/day b)2-3 } \\
\text { times/da c)3-4 times/day d) } \\
\text { none }\end{array}$ \\
\hline 3.Cleaning agents used & $\begin{array}{l}\text { a)Only water b)Water and } \\
\text { soap c)Water and antiseptics }\end{array}$ \\
\hline $\begin{array}{l}\text { 4.Habit of changing } \\
\text { absorbent in night }\end{array}$ & $\begin{array}{l}\text { a) Before going to sleep } \\
\text { b) At midnight }\end{array}$ \\
\hline $\begin{array}{l}\text { 5.Number Of Pads Per } \\
\text { Day }\end{array}$ & a) $1-2$ (b) $2-3$ (c) $3-4$ (d) $>4$ \\
\hline $\begin{array}{l}\text { 6.Taking bath during } \\
\text { menstrual days }\end{array}$ & $\begin{array}{l}\text { a) Once b) Twice c) } \\
\text { Thrice }\end{array}$ \\
\hline $\begin{array}{l}\text { 7.Use Of OTC } \\
\text { medication for pain } \\
\text { during menstruation }\end{array}$ & a)Yes b) No \\
\hline $\begin{array}{l}\text { 8.Places of drying cloths } \\
\text { (if used) }\end{array}$ & $\begin{array}{l}\text { a) Outside house in the } \\
\text { sunlight b) Outside house } \\
\text { without sunlight } \\
\text { c) Inside } \\
\text { house }\end{array}$ \\
\hline $\begin{array}{l}\text { 9. Method of disposal of } \\
\text { adsorbents }\end{array}$ & $\begin{array}{l}\text { a)Bury b)Burn c) With } \\
\text { domestic wastes d) } \\
\text { Throwing in open places }\end{array}$ \\
\hline 10.Storage places of pads & $\begin{array}{l}\text { a)Bathrooms b)Dress } \\
\text { cabinets c) Open shelves } \\
\text { d) Don't store }\end{array}$ \\
\hline
\end{tabular}

Table 2: Cleaning agents used.

\begin{tabular}{|lll|}
\hline Cleaning agents & Total number & Percentage \\
\hline Water & 93 & $50 \%$ \\
\hline Water and soap & 78 & $41.93 \%$ \\
\hline Antiseptics & 15 & $8.07 \%$ \\
\hline
\end{tabular}

Table 3: Habit of changing absorbent at night.

\begin{tabular}{|lll|}
\hline $\begin{array}{l}\text { Time of changing } \\
\text { absorbent }\end{array}$ & $\begin{array}{l}\text { Total } \\
\text { number }\end{array}$ & Percentage \\
\hline $\begin{array}{l}\text { Before going to } \\
\text { sleep }\end{array}$ & 153 & $82.25 \%$ \\
\hline Midnight & 33 & $17.74 \%$ \\
\hline
\end{tabular}

Table 4: Number of pads per day.

\begin{tabular}{|lll|}
\hline $\begin{array}{l}\text { Number of pads } \\
\text { per day }\end{array}$ & Total number & Percentage \\
\hline $1-2$ & 33 & $38.37 \%$ \\
\hline $2-3$ & 60 & $32.25 \%$ \\
\hline $3-4$ & 60 & $32.25 \%$ \\
\hline$>4$ & 33 & $38.37 \%$ \\
\hline
\end{tabular}

Table 5: Places of drying cloths (if used).

\begin{tabular}{|lll|}
\hline $\begin{array}{l}\text { Places of drying } \\
\text { cloths }\end{array}$ & $\begin{array}{l}\text { Total } \\
\text { number }\end{array}$ & Percentage \\
\hline $\begin{array}{l}\text { Outside house in } \\
\text { sunlight }\end{array}$ & 156 & $83.87 \%$ \\
\hline $\begin{array}{l}\text { Outside house } \\
\text { without sunlight }\end{array}$ & 24 & $12.9 \%$ \\
\hline Inside house & 6 & $3.22 \%$ \\
\hline
\end{tabular}

Table 6: Methods of disposal of adsorbents.

\begin{tabular}{|l|l|l|}
\hline Methods of disposal & Total number & Percentage \\
\hline Bury & 18 & $9.67 \%$ \\
\hline Burn & 126 & $67.74 \%$ \\
\hline With domestic waste & 30 & $16.12 \%$ \\
\hline Throwing in open places & 12 & $6.45 \%$ \\
\hline
\end{tabular}

Table 7: Storage places of pads.

\begin{tabular}{|lll|}
\hline Storage places & Total number & Percentage \\
\hline Bathroom & 114 & $61.29 \%$ \\
\hline Dress cabinet & 21 & $11.29 \%$ \\
\hline Open shelves & 48 & $25.8 \%$ \\
\hline Doesn't store & 3 & $1.61 \%$ \\
\hline
\end{tabular}

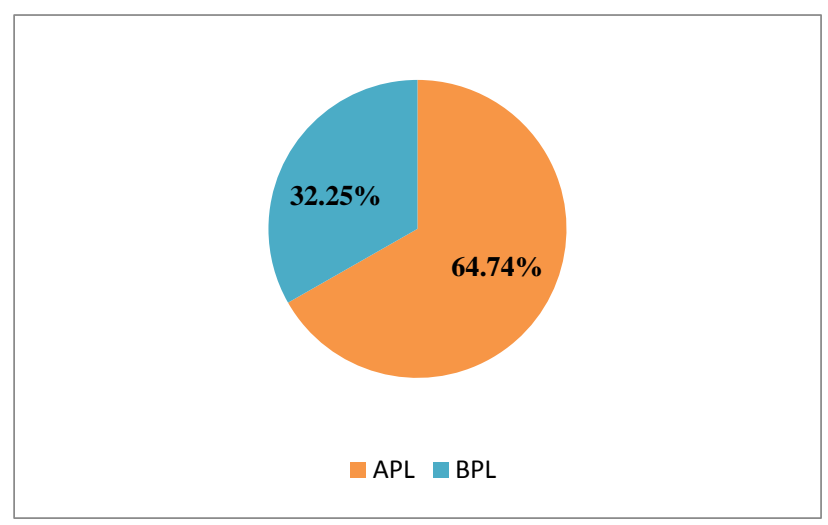

Figure 1: Distribution of APL and BPL based on economic status.

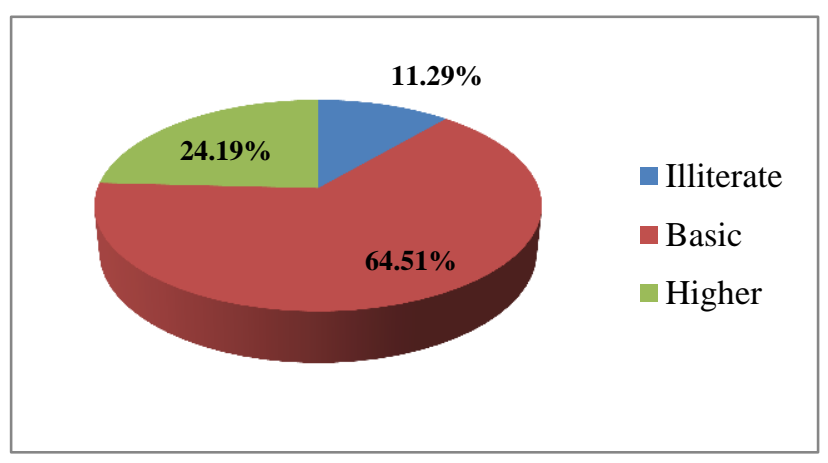

Figure 2: Patient educational status. 


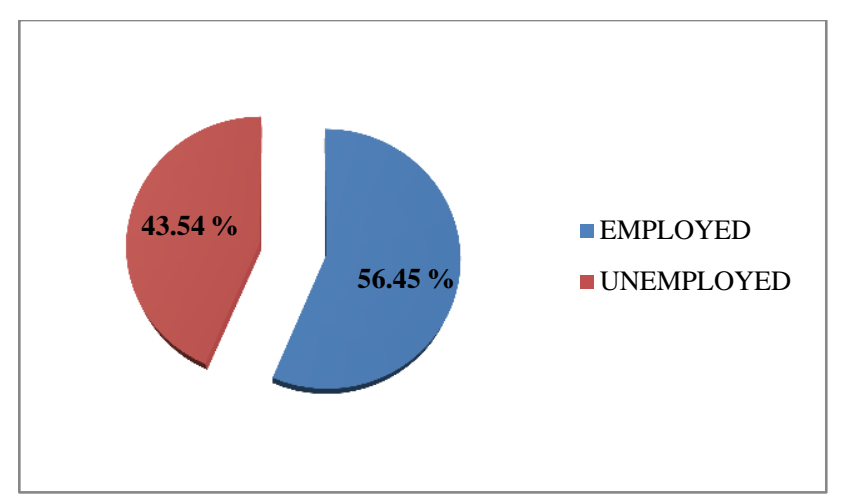

Figure 3: Patient occupation.

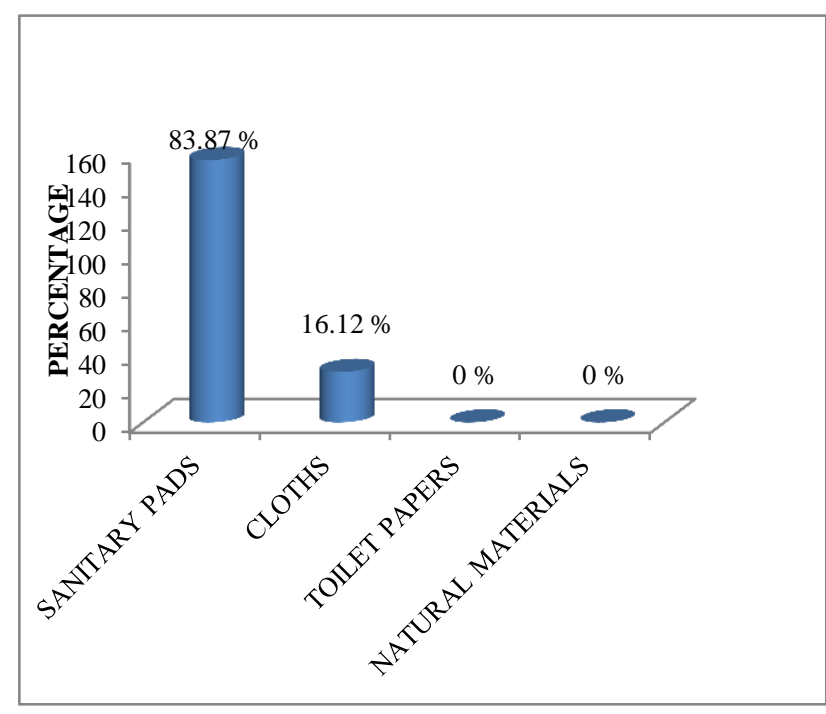

Figure 4: Materials used during menstruation.

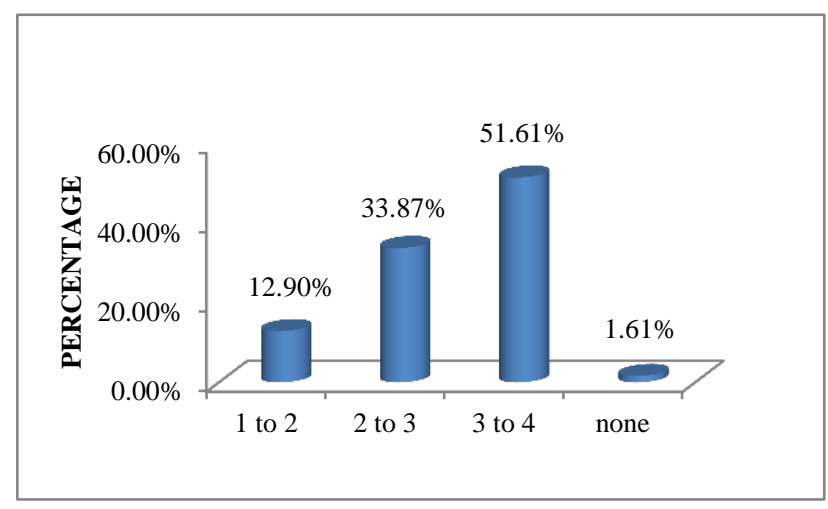

Figure 5: Frequency of adequate washing of external genitalia.

People who used cloths as hygienic material reused after washing it and the places of drying the washed cloths is depicted in (Table 5). The method of disposal of used pads were enquired, $67.74 \%$ of them burned, $16.12 \%$ dumped with domestic wastes, $9.67 \%$ buried in the premises and $6.45 \%$ threw in open places (Table 6). The general practice of storage was tabulated (Table 7).

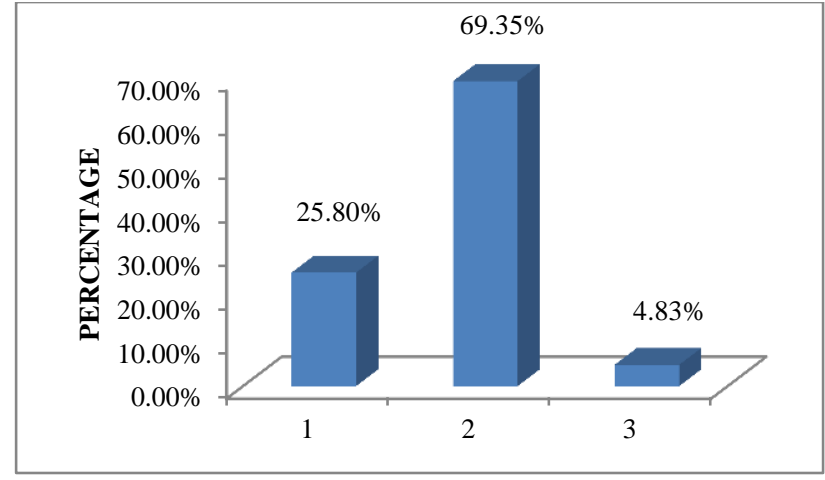

Figure 6: Frequency of bath.

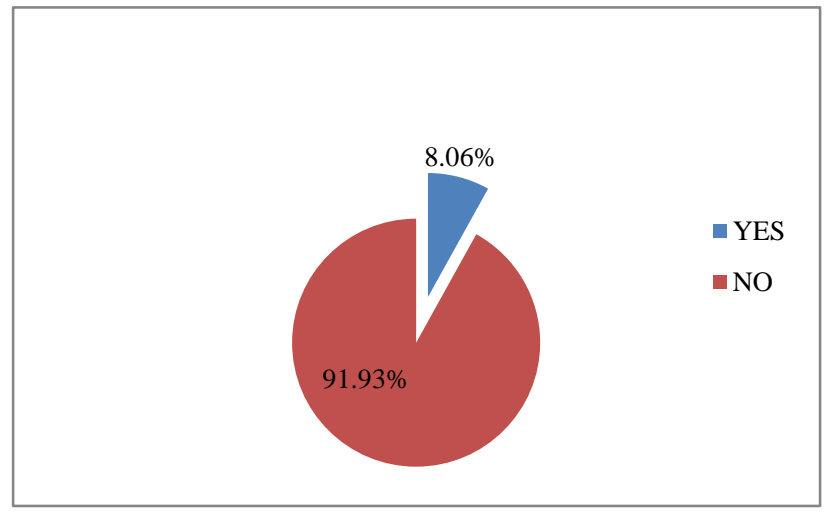

Figure 7: Use of OTC medications for menstrual pain.

\section{DISCUSSION}

Many of them were embarrassed in answering the questionnaires but at the same time some of them were keenly interested about the survey and showed a positive attitude towards the promotion of Menstrual Hygiene. ${ }^{4}$ The women and girls are refrained from various religious activities during menstruation, such as prayer, fasting, touching and domestic activities. ${ }^{4}$ Rethinking of the relevance of this practice is necessary in this fast growing world. Formal as well as informal channels of communication such as mothers, sisters and friends, need to be emphasized for the delivery of such information. In view of the vital role of the mothers, it is very important that the mother should be armed with appropriate information so that she can give knowledge to her growing girl child before puberty. Mothers were the commonest source $(38.2 \%)$ of information on menstruation as reported from the findings of similar studies done in other parts of India. ${ }^{8-10}$

In the study of Barathalakshmi et al., $90.5 \%$ of the respondents used disposable sanitary pads and the results of Zochukwu also showed $9.5 \%$ girls used old piece of cloth as absorbents. ${ }^{8,11}$ This finding is in contrast with the study conducted in Maharashtra, where only $15.6 \%$ girls used sanitary napkins. ${ }^{12}$ Many women stated that they experienced pain during menstruation, including headaches, stomach pains, painful breasts, joint pain, etc. 
which is caused by hormonal changes, and is often suffered in silence in societies. ${ }^{3}$ To maintain proper hygiene during menstrual days it is recommended to change the pads every 3 to 4 hours to avoid infections, foul odour, rashes, itching and other discomforts. ${ }^{9,14}$ External genitalia has its own mechanism of discharge to maintain the $\mathrm{pH}$ and hygiene. It is advised not to use soaps or other harsh cleansers which may alter the $\mathrm{pH}$. The use of water alone is best, also vaginal washes that does not alter the $\mathrm{pH}^{15}$

The knowledge about the disposal of used pads is essential as they influence the surroundings spoiling the aesthetic beauty of the place we live in and also cause air pollution during burning. A study by Upshae et al., provide evidence that still people use cloths, wash them and dry it in sunlight. ${ }^{7}$ Rural areas facilitates the burning and land-filling of general wastes as they have an access to vacant space. Moreover the practice of throwing away the used absorbents in drainage along with domestic waste is dangerous as it can clog the drainage system. The soiled pads thrown in open areas are a place for microorganisms to thrive in, which also make us and our pets to get into risks of high chances of diseases. A recent article in Hindustan Times highlights the problems in disposal of the used pads. The article, suggests that the safe way of disposal is incineration, the provisions in our country does not facilitate that practice. The current practice is land- filling and this non-biodegradable waste stays as such for about 800 years. ${ }^{16}$

It's of high importance to know about the storage of pads. It should be stored in a dry environment as they could absorb moisture from the environment, reducing the effectiveness when used. Whenever possible, keep disposable pads in the pack itself until you are ready to use them. It is advised to fold the pads in the packaging in way that, when they are opened, they are shaped conveniently for putting on. Studies by Omidiwar et al., and Narayan $\mathrm{K}$ et al., suggests that nearly half of the women store sanitary pads in bathroom, facilitates the growth of microorganisms. ${ }^{9,13}$ It is essential to train the teachers through workshops and awareness programmes to promote the hygienic practices. Including menstrual hygiene management in education policies should be ensured and taught to all girls.

\section{CONCLUSION}

This study primarily aims at assessing hygienic behaviour of adults during menstruation which needs more attention because of increased active participation in all walks of life, as lack of hygiene leads to serious infectious conditions and gynaecological problems. Our findings could not be fully generalized to the whole practice of females in the state but rather a common practice being followed due to factors like socio-economic status and their knowledge towards menstrual hygiene. A sustained public health awareness program can be developed to operate in population to create better awareness among women to manage their health and wellbeing. Government should initiate the steps to provide sanitary pads to make it affordable and to universalize the use of sanitary pads. The findings of the study reveal that a satisfactory result is obtained, however there is still space to improve the hygienic practices during menstruation.

\section{ACKNOWLEDGEMENTS}

Authors are thankful to the professors of Department of Pharmacy Practice and the hospital to complete this research successfully.

\section{Funding: No funding sources \\ Conflict of interest: None declared \\ Ethical approval: Not required}

\section{REFERENCES}

1. Ross and Willson.Anatomy and Physiology in Health and Illness. $11^{\text {th }}$ edition. Elsevier Publications.

2. Lawan UM, NafisaWali Yusuf, Aisha BalaMusa. Menstruation and menstrual hygiene amongst adolescent school girls in Kano, North Western Nigeria. African Journal of Reproductive Health. 2010;14(3): 201-8.

3. Menstrual Hygiene Management: Behaviour And Practices in the Lougaregion, senegal. Available at:www.unwomenwestandcentralafrica.com.

4. Vaughn JG. A review of menstruation hygiene management among schoolgirls in Sub-Saharan Africa.

5. Pokhrel S, Mahantashetti N, Angolkar M, DevkotaN. Impact of health education on knowledge, attitude and practice regarding menstrual hygiene among pre university female students of a college located in urban area of belgaum.IOSR Journal of Nursing and Health Science. 2014;4(3):38-44

6. Thakre SB, Thakre SS, Reddy M, Rathi N, Pathak K, Ughade S. Menstrual hygiene: knowledge and practice among adolescent school girls of saoner, nagpur district. J Clin Diagn Res. 2011;5(5):102733.

7. Upashe SP, Tekelab TF, Mekonnen J. Assessment of knowledge and practice of menstrual hygiene among high school girls in Western Ethiopia. BioMedCentral Women's Health. 2015;15:84.

8. Barathalakshmi J, Govindarajan PK, Ethirajan N, Felix AWA. Knowledge and practice of menstrual hygiene among school going adolescent girls. National Journal of Research in Community Medicine. 2014;3(2):138-42.

9. Omidwar S, Begum K. Factors influencing the hygienic practices during menses among girls from south India: a cross sectional study. International Journal of Collaborative Research on Internal Medicine and Public Health. 2010;2(12):411-23. 
10. Dasgupta A, Sarkar M. Menstrual hygiene: how hygienic is the adolescent girl? Indian J Community Med. 2008;33(2):77-80.

11. Amebue ZU.The impact of pre menarchial training on menarche practices and hygiene of Nigerian school girls. Pan African Medical Journal. 2009;2(9).

12. Udey AB, Keshwani N, Mudey GA, Goyal RC. A cross-sectional study on the awareness regarding safe and hygienic practices amongst school going adolescent girls in the rural areas of Wardha district. Global Journal of Health Science. 2010;2(2):225-31.

13. Narayan K. Puberty rituals, reproductive knowledge and health of adolescent schoolgirls in South India. Asia Pacific Population Journal. 2001;16(2):225-38.
14. Gynecologists ACOA. Menstrual Hygiene Products. Medical Library, 1997.

15. www.everydayhealth.com/.../hygiene-rules-for-ahealthy-vagina.

16. Available at:http://www.hindustantimes.com/healthand-fitness/ladies-be-careful-when-you-throwaway-the-sanitary-napkin/storyYnbqET6IzriWOy1Y8rFS8N.html.

Cite this article as: Geethu C, Paul EP, Thomas JE, Pullan CS, Hemalatha S, Sivakumar T. Appraisal of menstrual hygiene management among women in a rural setting: a prospective study. Int J Community Med Public Health 2016;3:2191-6. 